\title{
A Museum Picture Book as a Child's Entertainment Bridge to the Past and to the Richness of Heritage
}

\author{
Diana Zalar \\ Early Childhood and Preschool Education and Teacher Education, Faculty of Teacher Education, University of Zagreb, Croatia.
}

\begin{abstract}
How to cite this paper: Diana Zalar. (2021). A Museum Picture Book as a Child's Entertainment Bridge to the Past and to the Richness of Heritage. The Educational Review, USA, 5(3), 79-86.

DOI: 10.26855/er.2021.03.008
\end{abstract}

Received: February 12, 2021

Accepted: March 10, 2021

Published: March 30, 2021

Corresponding author: Diana Zalar, Early Childhood and Preschool Education and Teacher Education, Faculty of Teacher Education, University of Zagreb, Croatia.

Email: diana.zalar@ufzg.hr

\begin{abstract}
This research was conducted at the Faculty of Teacher Education in Zagreb. It is about the production of museum picturebooks in Croatia, their types, purpose and the ways in which children are involved in their creation or are encouraged to use them. What is special about picturebooks published by museums is their obvious intention to acquaint children and young people with times past as well as with numerous interesting details and facts associated with the past. It may be done by telling the tales which used to be passed from generation to generation, creating a simultaneity of two periods with the help of a supernatural being which gets into contact with a child of the present time, mentally reviving material monuments by returning to the times when they were built, telling of biographies of historical personalities or legends, inviting the reader to play with props which tell about times and situations from the near or ancient past, creating the interactive publications, reaching out with the help of digital technologies. This research should provide a basis for defining the concept of museum picturebook editions as a separate type of picturebook, artistic form or medium, and it should contribute to understanding educational use of museum picturebook editions for children.
\end{abstract}

\section{Keywords}

Museum Picturebook, Education, National Heritage, Children

The research at the Faculty of Teacher Education in Zagreb about Croatian museum picturebook as a heritage preserver was to focus on picturebook editions for children created during the last twenty years within the framework of museum activities. The intention was to include all the Croatian counties. Letters were sent to all addresses found in the document Register of Museums, Galleries and Collections in the Republic of Croatia, available on the Internet, containing a list of 281 museums ${ }^{1}$. Museum editions began to arrive. In the past few years, a number of valuable and interesting publications have appeared in a field which could be named museum publishing for children and young adults in Croatia. In addition to picturebooks, there are also carefully designed guide books, catalogues, leaflets and brochures, educational maps and didactic packs, popular science publications, manuals, thematic monographs, workbooks, worksheets. The picturebooks were to be catalogued and analysed in the course of the research: 1) according to the duality of discourse-visual and verbal, as well as the expressiveness of instrument of both; 2) a) according to correlations within a particular edition, especially as concerns its strategies for attracting the young reader's attention; b) according to the

${ }^{1}$ http://mdc.hr/hr/mdc/registar-muzeja/ 
correlations between groups of editions within a particular project or a particular activity in different institutions; 3) In the process, picturebooks were to be systematised according to the type and theme. Namely, at a random choice the mentioned editions seemed widely divergent in terms of their structure ${ }^{2}$. There is another aspect which makes museum picturebook editions an equal part of the national picture-book fund: all the literary genres, except novel, may be represented in the picturebook as the most complex form. The picturebook may narrate in verse or prose, and can tell its story simultaneously by picture and words. Furthermore, its textual part may be quite unpretentious from the literary aspect in order for it to still keep its artistic merit, for the very reason that it speaks through a dual language. Thus we came to the following conclusions:

I. The typology of museum publications is growing more complex, especially in the literary section, and particularly regarding picturebooks. They will be researched within the following categories: 1. Picturebooks mainly aimed at promoting museum collections - in verse/in prose; 2. Picturebooks not mainly aimed at promoting museum collections, but heritage-related; 3. Popular science and mainly educational picturebooks; 4. Biographical picturebooks about famous persons; 5. Alphabet picturebooks; 6. Toy picturebooks aiming at developing language and imaginative skills; 7. Picturebooks produced by children; 8 . Works between picture and illustrated books.

II. Many picturebooks, for instance, incorporate tasks for their young readers, such as writing or drawing something, etc., thus making them similar to worksheets. The picturebook resists the classification as a "pure" genre.

III. The publishing of museum picturebook editions is often associated with the museum special educational activities or certain thematic projects. In such instances, the picturebook is created as an organic part of the project, representing a kind of printed extension of the activity or project in question. Or, it is simply a written record of an exhibition, which makes it a catalogue as well. Besides giving the museum picturebook, a genuinely different status in comparison with other picturebooks printed in Croatia, all these facts also prompt further investigation. All over Croatia, museum activities are numerous and imaginative. Let us now take a more detailed look at the profiles and specificities of selected Croatian museum editions of picturebooks:

1. Picturebooks mainly aimed at promoting museum collections: a) Picturebooks in verse Salih Isaac, Wind in Winter, based on the picture of the same name by Dragan Gaži in 1973:

How should I paint the wind,/in winter, precisely?/Like snowy dust/ swirling, fuming!/ How should I measure her?/ To the boughs ruffled hair I'd paint, / All combed one way!/ And, what colour is the wind?/ Step on her tail with a brush, I will!/ Dress her into winter gowns,/ force her into naked crowns,/ and in the branchy bosom/ her sails entangle!/ In the lee the painter Gaži/ lurks, looking for the wind,/ Chasing, catching her in flight.../ His brush already frozen,/ covered in snow.../ Into the branches, their wicker/ Captured wind, winter... (Isaac, 2008)

\footnotetext{
${ }^{2}$ At present, there is a collection of almost thirty picturebooks at the Faculty of Teacher Education in Zagreb, two of which can be regarded as toys because they are intended for play and creating stories (below mentioned picturebooks):Salih Issac: Bucket at the Spring, Zagreb, 2008.; Salih Issac: Bird Ringing - Refrains of Paintings and Statuettes, Zagreb, 2010.; Božica Jelušić: The Little Drawing Book, Zagreb, 2011.; Zvonimir Balog, Arsen Dedić, Tonko Maroević: Games by the Water, Zagreb, 2012.; Pajo Kanižaj: Naïve painting with Haiku, Zagreb, 2007.; Luko Paljetak: Poems for Pictures,Zagreb, 2009.; Zvonimir Balog, Arsen Dedić, Salih Isaac, Božica Jelušić, Pajo Kanižaj, Tonko Maroević, Luko Paljetak (anthology ed.) Pictures Told in Verse, Zagreb, 2013. - all from The Croatian Museum of Naive Art, Zagreb; Sani Sardelić, the children of Smiljan: Nikola Tesla -Inventor of the Future, The Lika Museum in Gospić and the Korčula Town Museum, 2010.; Dubravka Rovičanac, Dubravko Kastrapeli: Franjo Žućak's Insect Collection, The Varaždin City Museum, 2008.; Dubravka Rovičanac, Dubravko Kastrapeli: Franjo Žućak in the Old Town of Varaždin, The Varaždin City Museum, 2009.; The children of kindergarten Sister and brother: The Many-Coloured Cockerel, The Slavonski Brod Fine Arts Gallery, 2013.; Jasen Boko, Edvin Dragičević: Tales from the Museum, The City Museum of Split, 2010.; Mario Klarić, Zoran Perdić Lukačević: The Story of the Vitturi Castle in Kaštel Lukšić, The Kaštela Town Museum, 2011.; Stanislav Marijanović: Monsters in the Museum or the $1^{\text {st }}$ War of Tvrđa against as yet Unknown Monsters], The Museum of Slavonia in Osijek (n.d.).; Damir Lacković, Trpimir Vedriš: Droplety and the Stone, The Croatian Natural History Museum in Zagreb, 2008.; Ibrahim Agačević, Zoran Perdić Lukačević: The Story of Gaius Laberius, The Trilj Regional Museum, 2009.; Pajo Kanižaj, Barun Niko, Krešimir Šoštarko: The Neanderthals of Krapina and their Kids, ART STUDIO and The Museums of Hrvatsko Zagorje-The Museum of Evolution and the Archaeological Site of Neanderthals "Hušnjakovo" in Krapina, 2006.; Ivica Antolčić and Ljubica Koren Željkova: A Story from the City of Bees, The Technical Museum in Zagreb, 1997.; Dubravko Mihanović, Srđana Modrinić: A Short History of Zvane the Unworthy, the Lord of Sinčić Palace (a story of two different times], The Heritage Museum of Poreč, 2009.; The children of the Italian kindergarten and the residents of the Nursing home in Novigrad: Granny's Notebooks: Marcella's Truth, Novigrad, 2012./Granny's Notebooks: Granny Argia's Cockerel, Novigrad, 2013./Granny's Notebooks: The little red shoes: Fear has Big Eyes, Novigrad, 2014./Granny's Notebooks: Tricks from Times Past, Novigrad, 2010. - all picturebooks from The Lapidarium Museum in Novigrad; The children of the kindergartens MyrtleandBees: The Titanic and the Carpathia: Children Recount, The Maritime and History Museum of the Croatian Littoral in Rijeka, 2012.; Cvija Branka and the children of the kindergarten "Radost (Joy)": Vila Markačeva [The Markaci Fairy] (according to Lojza Jurić), The Crikvenica Town Museum, the kindergarten "Radost (Joy)" in Crikvenica and the City of Crikvenica, translated into English by Denisse Mandekić, 2011.; Izabela Peculić: Karolina: Playing at the Museum and the Museum at Play, The Maritime and History Museum of the Croatian Littoral in Rijeka, 2013.; Margita Cvijetinović Starac (ed.): Let's Learn the Glagolitic Alphabet, The Maritime and History Museum of the Croatian Littoral in Rijeka, 2007.; Renata Brezinščak, Ivanka Borovac: The Geological Alphabet Picturebook], The Croatian Natural History Museum, Zagreb, 2013.; Maja Čizmić Regula: The Little Storytelling Box (Regoč), Ivana's House of Fairy Tales and the Town of Ogulin Tourist Office, 2013.; Maja Gjajić: What is a Museum?, The Požega City Museum in Požega, 2010.; Jelena Hihlik: The story of a Coin, The Pakrac Town Museum, Pakrac, 2013.
} 
The following seven picturebooks published by the Croatian Museum of Naive Art (CMNA), Bucket at the Spring, Bird Ringing - refrains of pictures and figurines, Little Drawing Book, Games by the Water, Naïve Painting with Haiku, Poems for Pictures and Pictures Told in Verse, are this year's results of a long-term project aimed at getting children and adults acquainted with and making them aware of the existence and qualities of Croatian naive art. The project was started in 2005 with the first interactive CD called Welcometo the World of Naive Art, and has been continuously developing and expanding. In the past eight years of intense activity involving an imposing number of children, artists and experts from various fields, the pictures and sculptures by Croatian naive artists have served as the source of creative work. Every year on the occasion of the International Museum Day and Museum Educational Action Day, one picturebook was published as a material proof of this collaboration. The picturebooks were all created in CMNA workshops. Numerous associates, visual artists and teachers have been involved in this project together with a large number of children. Already at first glance one can notice the interesting varieties of graphic design (the picturebook Bucket at the Spring was published in the form of a postage stamp where the naive artists' names and biographies are printed as page markers, the reproductions and children's drawings on the right pages, and Salih Isaac's poems on the left ones). But what makes these picturebooks special is their complexity, the interrelation of three distinct levels. In each of these picturebooks, photographs depicting selected naive artists' works are newly juxtaposed with poems by Croatian poets dedicated to those works, but also with children's art inspired by the same pictures and sculptures. Children aged seven to fifteen were encouraged to look at the art and think about it, and under the guidance of experts this process resulted in their original creations. Poets were also involved in the project. This project was presented under the title Naive Art is Always a Pleasant Surprise - Let's Create a Picturebook, within the overall museum educational action Surprise. The symbolism of this picturebook project is contained in several levels: firstly, the project comprises poems both in the standard literary idiom (Štokavian) as well as those in the Kajkavian and Čakavian dialects, which adds a linguistic angle to the visually expressed unity of the Croatian regions from which our naive artists originated. It all began with works of art which are original by global standards, and therefore belong to the Croatian national treasure. Thus the picturebook becomes a way to enjoy the national heritage. Secondly, the themes are emblematic: the beauty of nature and its annual changes on the continent as well as near the sea; biblical and religious themes; the singularity of portrait painting; the world of animals and plants; the urban experience. Different writers had the opportunity to talk about the same painting or a chosen detail. The differences in their associations, impressions and imaginative creations are clearly visible. These editions enable one to perceive the line of systematic research into the communicative (receptive), semantic, aesthetic and culturological aspects that were the sources of the best works of naive art. There is an additional level of symbolism, as well as the receptive code: after a long period in the Croatian literary scene in which the publishing of poetry, and especially poetry for children, had been largely neglected, this project opened the doors to poetic creations for all generations. Not all the poems collected in the seven mentioned books are superior works of art, but the best of them satisfy the aesthetic and intellectual needs of children, teenagers, as well as adults at different levels. The CMNA project has been conceived along these lines and puts the children and adults on an equal footing, enabling them to embark on a wonderful adventure together. In the process of artistic creation undertaken together by the painters, sculptors, poets and children of different generations and periods, bridges can be built even across time distances. The picturebook promotions at the Mimara Museum brought together singers, children artists and experts under whose guidance the books came to life, turning into real concerts where the audience sang together with the performers.

b) Picturebooks in prose: Franjo Žućak and the Insect Collection and Franjo Žućak in the Old Town of Varaždin are good examples of books in which the didactic purpose is playfully intergrated into an appropriate story. In this case, the story is about an entomological collection and about how to behave when visiting a museum. One book talks about Franjo Košćec, the well-known Croatian natural scientist, professor and founder of the Entomological section of the Varaždin City Museum, and was created as part of the projects organised within the programme Franjo Košćec and His Work. The title character, museum employee and admirer of Košćec's work Franjo Žućak, has the power to occasionally turn into a butterfly, and on one of his flights around Varaždin he gets to know the family which he then brings to the museum. Here the story of the other picturebook starts, in which the family members compete as to who will be on their best behavior at the museum. The children win over their parents, and on the last page the books gives an overview of the Golden rules of museum etiquette. The pastel illustrations, done in light, bright colours, seem warm and slightly ethereal. Smiling faces peep from every page. With their drawings, playful stories and merry colours the picturebooks really make us want to visit the museum.

The Story of a Coin by Jelena Hihlik is not conceived ambitiously, but its charm lies in the clear wish to bring closer to Croatian children a few interesting facts about the town Pakrac and the great value of the coins that were created there during the Middle Ages (in the $13^{\text {th }}$ century) and which provided the inspiration for the Croatian currency in use today. 
Once upon a time there was an old coin called the Slavonic banovac. Although small, its value is big, it was made of silver, and because of its beauty it is considered to be one of the most beautiful Croatian and European coins (Hihlik, 2013).

The picturebook has no literary pretensions. The illustrations are a mixture of computer drawing and pasted photographs. The text addresses younger children.

2. Picturebooks not mainly aimed at promoting museum collections, but heritage related: A Short History of Zvane the Unworthy, the Lord of Sinčić Palace (a story of two different times) by Srđana Modrinić and Dubravko Mihanović is a very ambitiously designed modern book. As the blurb says, it was printed on the occasion of the $125^{\text {th }}$ anniversary of the establishment of the Poreč Museum Institution. The illustrations, set within the book's space in a variety of ways, are witty and dynamic. A word about their visual relationship to the text: the text is embraced by the drawings, together with an old topographic map, a recipe for cookies kroštulas, the Sinčić family coat of arms, or in the darkness of the night sky lit only by a streetlight, printed on the sack into which the story's characters are cramming their treasures... On one page the text is printed in the shapes of the plots of land that Zvane the Unworthy talks about, with flies, disturbed by a cow's tail swishing, buzzing around it; on two other adjacent pages, it is written by hand on the parchment on which Zvane's wife had written her last will. Some additions to the text are written by hand rather than in printing, and the integration of text and illustration is also achieved by the extremely playful drawings in which colour is employed merely to accentuate certain parts of the drawing, whereas the remaining parts are colourless, like an extended game of letters that have lent themselves to imagination—besides telling a story by words, they also tell it with their chosen shapes and details. Such a graphic and design concept results in the unique, individual breeziness of the book, leaving the strictly defined page limits and softening the hardness of the book's covers. Still savouring the impression that leafing through this extraordinary work leaves us under, let us now turn to reading and the story. In consistence with the concept that every two adjacent pages present a different visual experience, this is the way the story is divided into separate chapters. The introductory part is followed by An Unusual Event, in which we meet the boy called Marko, and which announces his slightly scary meeting with his 300 years older fellow-citizen Zvane (the ghost of Sinčić Palace); the following two adjacent pages are titled Palace for Romantics and acquaint the reader with the peculiarities of this important building from $17^{\text {th }}$ century Poreč; The Comet tells about the Sinčić family coat of arms; the part called Toys brings the reader back to the $21^{\text {st }}$ century boy from Poreč and the problem of egoism and greed that runs through the text as a leading motif and link between the two main characters... somewhere in the sixth part titled More, the boy Marko finally sees through Zvane's intentions and understands the message of his story. Each of the chapters starts with a new narrative position, relating to one of the boy's questions or associations, to an eventor an interesting historical fact. The text is slightly incoherent on purpose, since the narration is interrupted by demographic data, explanations of historical facts, building details etc. This has a double effect: firstly, such a compartmentalisation of the story makes non-linear reading possible, enabling the reader to return to the more interesting bits or go through the book from end to beginning - without hampering the understanding, which makes the book stand at par with the new digital technologies that provide all these possibilities. On the other hand, certain flaws exist which may have been avoided with timely cuts and rephrasings. A Short History of Zvane the Unworthy, the Lord of Sincić Palace is one of the best Croatian museum picturebook editions. Along with the awareness about our rich heritage, it reminds the children that life should not be wasted in greed and loneliness, but spent in sharing and love.

The edition named Granny's Notebooks-I quaderni della nonna (Granny Argija's Cockerel, Marcella's Truth, Tricks From Times Past, The Little Red Shoes) represents part of a long-term project started in 2005, whose aim is trying to save from oblivion and revive the values and contents of one region's collective memory. They refer to the collective memories and tales which were passed on orally from generation to generation in the north-western part of Istria, where the Lapidarium Museum (Novigrad) is located. These books have a very complex structure. They comprise the features of picturebooks, workbooks and worksheets, cookbooks and autograph books; parts of them may be turned into picture postcards and sent back to the project leaders in order to provide them with feedback on the books. Although these bits interrupt the story and illustrations, they are inserted in relation to the development of the storyline, thereby probably inviting a conversational reading mode, which would involve talking with the children about particular segments of the story and associations they might invoke. The books also provide links to webpages where the children can find numerous further ideas and contents associated with the story, with history in general and the current project. The books of this edition gathered a large number of collaborators, just like it was the case with the picturebook editions of the Museum of Naive Art. They were illustrated by the children from the Italian Kindergarten in Novigrad, and the childhood stories were told by the residents of the Nursing Home from the same city, who either narrated their own experiences or told stories that they had heard from members of their families a long time ago. The many carefully drawn illustrations are supplemented with photographs of objects and events belonging to the cultural and historical heritage. 
The books also contain prefaces written by ethnologists or pedagogues, as well as psychologists who explained the various dimensions of these books from different aspects. The stories have been carefully selected and deal with important topics such as alcoholism in the family, neighbourly relations or different dimensions of life in the past like food, education, religion and games. All parts of the texts are written in two languages, Croatian and Italian (due to the population structure in that region of Croatia). The stories are very honest and open, without much embellishment. There are no unconvincing happy endings, so typical of children's literature. This is a very important feature of these books, since they do not underestimate the children's perceptive powers, and encourage them to participate with adults as equals in thinking about heritage. Another important quality of this project is the fact that it brings together the youngest and the elderly, not only by the stories themselves, but also physically, through conversations, visits and mutual respect. The stories are interrupted by numerous tasks and other kinds of printed materials. This reading mode is rapidly developing under the influence of the media and digital technologies, whose particularities help creating readers with multidimensional reading skills.

The Story of Gaius Laberius by Ibrahim Agačević and Zoran Perdić Lukačević, a picturebook published by the Trilj Regional Museum, tells about an ancient gravestone of a boy whose life story might only be guessed at; the authors used their imaginations to create a tale with a patina of the past. At the beginning, the reader's curiosity is awakened by some known facts:

This is the story of GAIUS LABERIUS VALES, a Roman boy who only lived to the age of seven, in the valley of the river Cetina, almost 2,000 years ago. His gravestone was found on Gardun, and was built into the wall of the Perković house in Sinj 150 years ago. It has been standing there ever since. (Agačević, Perdić, 2009).

An illustrated story follows, ending with a quote of the words engraved into the stone, in Latin, Croatian and English:

Your faithful friend these lines engraved:/ and paid his debt to you - 'tis all I able was to do./ Don't cry, Mother, my cruel fate this was./ Alas, too soon my hair turned white, may the stars shine on me their gentle light./ Farewell my dear, and may they soothe your sorrow, those who born were afore. (Agačević, Perdić, 2009)

The gravestone inspired the authors to imagine and create a story about a demobilised Roman soldier who was given a bit of land in the region of today's Trilj in Croatia, and came to live there with his family. On one occasion, his son Gaius almost drowned, but was saved by another boy, who became his closest friend until Gaius fell ill and died. The stone is the more interesting because it was erected by Gaius's friend, probably just a boy himself. These are the facts that the story is built upon. Thus, no less than three discourse codes are present: 1 . the words carved in the stone; 2 . the Latin (original) wording, as well as the Croatian and English versions; 3. the story told in a contemporary way of perception. Those codes are combined with the illustrations to create a fictionalised reality of ancient Rome in the Croatian territories. At the end there is a supplement containing elaborate explanations of less known facts (Baton's uprise, Delmates, Roman military diploma, etc.). The picturebook talks about friendship and loyalty. This way the mysterious gravestone that belongs to heritage and history links the contemporary child with the one that lived in the same territory in ancient times. By showing that loyalty and friendship among children existed in those times too, the stone is the link which makes the past less unfamiliar and distant.

3. Popular science and mainly educational picturebooks

The book Droplety and the Stone, written by engineer of geology Damir Lacković and illustrated by Trpimir Vedriš, is one of the best picturebooks published by Croatian museums, since its interesting text enables readers from all age groups to get acquainted with the phenomena of mountain karst in an easy and fun way. The illustrations are excellent and witty, and the special points of interest are emphasised on the pages in contrasting colours. Drops of water are depicted as living organisms and thus turned into characters in the story. It is a story about

(...) drops of water and little calcite crystals which together form an unusual landscape - karst - from limestone. The story begins a long time ago, it goes on today, and will continue tomorrow, and start and continue again for a long time to come... The water drops form a huge cloud. They are warmed by the Sun from above, and drawn and lured by the Earth from below. They long to leap down, into the grass.(...) (Lacković, Vedriš, 2008)

The droplets "lick" the stone, slide down the rocky slopes of the limestone, "nibble" at it, and alter the appearance of karst in this cheerful game. They form little rocky pools, meet the calcite crystals, and journey together through cracks in the earth. So the story gradually explains the way caves or pits come into being, accompanied by information on the best known caves and their features of interest, which prompts conversations and the search for additional facts from books or other media. In the same accessible and interesting mode stalactites and stalagmites are discussed, as well as waterfalls turned to stone and the various forms that the limestone is turned into within the caves. In the end, the reader is warned about water pollution, and the droplet evaporates into the air. The circle is completed, and can start again... Each copy of picturebook has been printed in one of four languages - Croatian, English, German and Italian. 
4. Biographical picturebooks about famous persons

Nikola Tesla, Inventor of the Future was written at the suggestion of Sani Sardelić, curator of the Korčula City Museum, who recognised the importance of the workshop organised by elementary school teacher Ivica Franić at the regional school in Smiljan, the birthplace of Nikola Tesla. At the Nikola Tesla Memorial Centre a project was started with the participation of children across various age groups from Smiljan, involving making pictures of Tesla's inventions in different techniques and forms. As the book has been written in the confessional first person, it was possible to refer to concrete situations. The children's illustrations are great, rich with colour and an inner life, or, to put it more appropriately-electrified. They carry this picturebook, which is also unique because it is the result of a cooperation by the two museums.

5. Alphabet picturebooks. The Geological Alphabet Picturebook by Renata Brezinščak and Ivanka Borovac belongs to the subcategory of alphabet picturebooks, but its primary purpose is not to teach children about letters, but to introduce them to the world of geological concepts. It has been written in fluent rhymes, and on its back cover, together with a picture of the Croatian Science Museum building, the following welcome greeting has been printed:

We know that knowledge / is more valuable than gold; so that we who here abide, / keep our door open wide / to all our students present and past. /And warmly welcome you at last! (Brezinščak, Borovac, 2013)

Let's Learn the Glagolitic Alphabet is an extraordinary picturebook created from Glagolitic letters made by pupils of the Nikola Tesla Primary School in Rijeka, under the guidance of sculptress Milijana Babić and art teacher Ivan Markovčić, and based on the theme of Museums and Universal Heritage. By depicting one of the Glagolitic letters on each page, the whole picturebook represents the Baška tablet, old croatian monument (1100 AD). At the bottom of each page, there is a note about the sequence of letters depicted on the previous pages. The letters were made in various techniques (paper mache, plaster casting, collage, cardboard cutouts, wrapping in straw, artificial flower sculptures...), thus creating each letter in a different attire made from newspapers, plastic, jute, glittering aluminium foil, multi-coloured viscose and other fabrics used in the production of clothes, crêpe paper, tempera, corrugated cardboard, paper napkins, biscuits etc.). Each page surprises the eye anew, since the created letters have been photographed against the white background of the page without text. The feast of imagination, colour and materials comprised on these pages also makes us notice that many of the Glagolitic letters contain apertures in the form of little windows in all forms imaginable. This way an implied dramatics is created, a personalisation of the little sculptures. The letters on the cover are purposefully chosen to suggest a perspective of the letters turned to the viewer, challenging him/her to "look into their eyes”. Through such a playful approach the letters almost become characters in a story, flying off into space, and the little windows turn into eyes which look at us, expecting something to happen... here the implied story for the reader starts.

6. Toy picturebooks aiming at developing language and imaginative skills. Karolina-Playing at the Museum and the Museum at Play is a toy picturebook based on the history of Karolina Belinić, a woman from Rijeka who saved the city from destruction in 1813 when the English fleet, at war with Napoleon's army, started bombarding the city. The lavishly designed, attractively coloured map contains a little figure of Karolina of Rijeka and pockets with dresses from different historical periods (with magnets, so that the doll can change costumes), various items worn on walks in the past (a monocle, fanetc.), postage stamps, picture postcards of Rijeka from a hundred years ago and a booklet describing the event of 1813 on a few pages in simple terms, in Croatian and English. The map opens with a view of the city of Rijeka as it was in Karolina's time, hiding the above-mentioned items. It was created as part of the project Karolina Knows, and conceived and designed by artist Izabela Peculić. This was a special and children-friendly way to mark the $200^{\text {th }}$ anniversary of that somewhat mysterious event. The workshop partcipants were able to dress Karolina in period costumes and place her in different settings and historical contexts with the help of particular websites, thus providing this toy picturebook with a multimedial extension and an additional dimension. The book does not contain a literary text.

7. Picturebooks produced by children. The Titanic and the Carphatia-Children Tell a Story is a picturebook written in children's handwriting and illustrated with children's drawings. In their kindergarten group, preschoolers Lovro, Adrian and Bartol learned about and discussed the well-known event from maritime history that happened in 1912, the sinking of the steamship Titanic and the rescue of its passengers by the crew of the Carpathia, which first reached the scene of the disaster. The book's cover is very suggestive: at the blue bottom of the sea, a ship has been sculpted from paper mache, and the smoke from its chimneys forms the letters of the title. The text tells about the building of the ship and the most dramatic moments of the catastrophe. Everything happens on the right pages of the picturebook, and the left ones have been left blank, inviting the reader to draw his/her own story. It is assumed that this way each copy of the book is meant to become a dual work - a product made by the reader and by the children of Rijeka.

The Many-Coloured Cockerel, a story told and illustrated by children from the middle and older groups of the "Sister and Brother" kindergarten in Slavonski Brod came into being from an interesting impulse. Viewing the artifacts dis- 
played in the permanent collection of the Ružić and Contemporaries Gallery in Slavonski Brod, the children imagined the pieces as characters of a story. The exhibits in question were sculptures by Vjekoslav Vojo Radoičić (My Little Rose, 1991, painted wood), Slavko Kopač (The Violin Player, 1980, aluminum), Zvonimir Lončarić (Franjo at the Cafe, undated in the picturebook, bronze), Vasko Lipovac (Sailor, 1997, painted wood) and Ljubomir Strahov (Rooster, undated in the picturebook, terracotta). The children participated in the workshop as part of the educational action Museum Storytellers, on the occasion of the International Museum Day on 18 May 2013. The plot shows how it is possible to imagine a dynamic adventure story based on something actually seen.

\section{Conclusion}

When discussing museum picturebook editions in Croatia, several aspects have to be taken into consideration. First and foremost, there are the annual thematically organised activities. There are also instances of picturebook sequences based on the annual themes. Some editions clearly indicate the attitude of considering dialects and the standard literary language on an equal footing, since both are equally represented in the same picturebook. There are also bilingual editions which acknowledge the bilingual communities they originated from. Some editions of the same picturebook are printed separately and simultaneously in Croatian as well as in several other languages. There are various strategies of securing the reader's attention. In some instances, the aspect of authorship is the interesting part, when anonymous young individuals from different schools and kindergartens get the chance to participate in the creation of a book, sometimes along with renowned writers and visual artists, and sometimes on their own or under the guidance of a professional from the fields of art, pedagogy or education. Sometimes children are simply being creative alongside older people, as in the picturebooks of the Granny's Notebooks series. In that sense, their work addresses people of all generations. If we consider the involvement of children and adults in organised projects and workshops within the museums' educational activities, it is considerable number growing concentrically. We must not forget the building of bridges between generations achieved by such projects (even among people who do not speak the same language); here we reach the area of a very special communication strategy with readers which is sometimes attained by museum picturebook editions. The most difficult aspect of such modern picturebook concepts is finding an appropriate balance and harmony between the traditional and the exciting possibilities of contemporary expression.

What is special about picturebooks published by museums is their obvious intention to acquaint children and young people with times past as well as with numerous interesting details and facts associated with the past. The ways used to achieve that aim are worth investigating. It may be done by telling the tales which used to be passed from generation to generation, creating a simultaneity of two periods with the help of a supernatural being which gets into contact with a child of the present time, mentally reviving material monuments by returning to the times when they were bulit, telling of biographies of historical personalities or legends, inviting the reader to play with props which tell about times and situations from the near or ancient past. We must also add the interactive publications, reaching out with the help of digital technologies, so that may be enriched with additional attractive contents by means of the Internet. The picturebook represents the basic genre introducing children into the world of written word and visual art. Museum picturebook editions have yet another dimension, as they direct our attention towards a part of a national heritage, and raise our awareness of it, which gives them a special purpose and value. For this reason, this research should provide a basis for defining the concept of museum picturebook editions as a separate type of picturebook, artistic form or medium, and it should contribute to understanding reception and educational use of museum picturebook editions for children.

\section{References}

Agačević, I., Perdić, L. Z. (2009). Priča o Gaju Laberiju (The Story of Gaius Laberius). Trilj: The Trilj Regional Museum.

Balog, Z., Dedić, A., and Maroević, T. (2012). Igre uz vodu (Games by the Water). Zagreb: The Croatian Museum of Naive Art.

Batinić, Š. and Majhut, B. (2017). Hrvatska slikovnica do 1945. Zagreb: Hrvatski školski muzej, Učiteljski fakultet.

Brezinščak, R. and Borovac, I. (2013). Geološka slovarica (The Geological Alphabet Picturebook). Zagreb: The Croatian Natural History Museum.

Cvijetinović, S. M. (2007). Učimo glagoljicu (Let’s Learn the Glagolitic Alphabet). Rijeka: The Maritime and History Museum of the Croatian Littoral in Rijeka.

Grilli, G. (2020). The New Non-Fiction Picturebook for Children: Mending the Rift between Science and Art. Libri et liberi, 9(1), 75-89.

Hihlik, J. (2013). Priča o novčiću (The story of a Coin). Pakrac: The Pakrac Town Museum.

Issac, S. (2008). Vjedro na izvoru (Bucket at the Spring). Zagreb: The Croatian Museum of Naive. 
Issac, S. (2010). Prstenovanje ptica—Dopjevcii prepjevci slika ik ipića (Bird Ringing—Refrains of Paintings and Statuettes). Zagreb: The Croatian Museum of Naive Art.

Jelušić, B. (2011). Slikopisanka mala (The Little Drawing Book). Zagreb: The Croatian Museum of Naive Art.

Kanižaj, P. (2007). Naiviku sliku uz haiku (Naïve painting with Haiku). Zagrfeb: The Croatian Museum of Naive Art.

Kümmerling-Meibauer, B., Meibauer, J. (2019). Picturebooks as Objects. Libri et liberi, 8(2), 257.

Lacković, D., Vedriš, T. (2008). Kapljica ikamen (Droplety and the Stone). Zagreb: The Croatian Natural History Museum in Zagreb.

Majhut, B., Zalar D. (2012) Slikovnica. In: Hrvatska književna enciklopedija, edited by Visković, Velimir. (sv. 4, S-Ž). Zagreb: Hrvatski leksikografski zavod Miroslav Krleža.

Margarida Ramos, A. (2020). Picturebook Format: Beyond the Relationship between Words and Pictures. Libri et liberi, 9(1), 61-74.

Mihanović, D., Modrinić, S. (2009). Kratka pripovijest o Zvanetu Nedostojnom, gospodaru Palače Sinčić (A Short History of Zvane the Unworthy, the Lord of Sinčić Palace). Poreč: The Heritage Museum of Poreč.

Mileusnić, R. (2018). Muzejske publikacije za djecui mlade ( $2^{\text {nd }}$ ed.). Zagreb: Muzejski dokumentacijski centar.

NarančićKovač, S., Milković, I. (Eds.). (2019). Prijevodi dječje književnosti. Pogled iz Hrvatske. Proceedings from HRZZ BIBRICH: Building Intercultural Bridges through Children's Literature Translations: Texts, Contexts and Strategies. Zagreb: Učiteljskifakultet

NarančićKovač, S. (Ed.) (2019). Hlapić u bijelom svijetu. Proceedings from HRZZ BIBRICH: Building Intercultural Bridges through Children's Literature Translations: Texts, Contexts and Strategies. Zagreb: Učiteljski fakultet.

Paljetak, L. (2009). Pjesme za slike (Poems for Pictures). Zagreb: The Croatian Museum of Naive Art, Zagreb.

Peculić, I. (2013). Karolina—Igra u muzejui muzej u igri (Karolina—Playing at the Museum and the Museum at Play). Rijeka: The Maritime and History Museum of the Croatian Littoral in Rijeka.

Rovičanac, D., Kastrapeli, D. (2008). Franjo Žućak i zbirka kukaca (Franjo Žućak and the Insect Collection). Varaždin: The Varaždin City Museum.

Rovičanac, D., Kastrapeli, D. (2009). Franjo Žućak u varaždinskom Starom gradu (Franjo Žućak in the Old Town of Varaždin). Varaždin: The Varaždin City Museum.

Sardelić, S. (2010). Nikola Tesla—izumitelj budućnosti (Nikola Tesla—Inventor of the Future). Korčula: The Lika Museum in Gospić and the Korčula Town Museum.

The Lapidarium Museum in Novigrad. (2012). Bakine bilježnice - I quaderni della nonna: Istina o Marcelli - La verita di Marcella (Granny’s Notebooks: Marcella’s Truth). Novigrad.

The Lapidarium Museum in Novigrad. (2005). Bakine bilježnice - I quaderni della nonna: Il galletto di nonna Argia - Pjetlić bake Argije (Granny’s Notebooks: Granny Argia’s Cockerel). Novigrad.

The Lapidarium Museum in Novigrad. (2014). Bakine bilježnice- I quaderni della nonna: Crvene cipelice u strahu su velike oči - La scarpette scarlatte quando la paura fa novanta (Granny’s Notebooks: The little red shoes: Fear has Big Eyes). Novigrad.

The Lapidarium Museum in Novigrad. (2010). Bakine bilježnice- I quaderni della nonna: I trucchidei tempi passati - Trikovi izprošlih vremena (Granny’s Notebooks: Tricks from Times Past). Novigrad.

The Maritime and History Museum of the Croatian Littoral in Rijeka. (2012). Titanic i Carpathia: Djeca pričaju (The Titanic and the Carpathia: Children Recount). Rijeka.

Zalar, D., Boštjančić, M., and Schlosser, V. (2018). Slikovnicai dijete, kritičkai metodička bilježnica (5 ${ }^{\text {th }}$ ed.). Zagreb: Golden marketing-Tehnička knjiga. 